\title{
The dance between artefact, commodity, and fetish: A case study of Brendan Fernandes' Lost Bodies
}

\author{
Sharday Mosurinjohn
}

School of Religion, Queen's University, Kingston, Canada

Sharday Mosurinjohn is Assistant Professor in the Contemporary Religious Context and can be contacted at Theological Hall 230, School of Religion, Queen's University, K7L 3N6.

Phone: 613-533-6000 x.74313. Email: sm110@queensu.ca.

Sharday Mosurinjohn (BA [Museology, Sociocultural Anthropology], University of Western Ontario; MA, PhD [Cultural Studies], Queen's University) is Assistant Professor (Contemporary Religious Context) at the School of Religion at Queen's University, Kingston, ON. 


\section{The dance between artefact, commodity, and fetish: A case study of Brendan Fernandes' Lost Bodies}

In 2015 artist Brendan Fernandes was invited to interpret 'African collections' from the Agnes Etherington Art Centre and the Textile Museum of Canada. The result, Lost Bodies, critiques racist ideologies that justified presenting objects from colonized African peoples as evidence of 'superstition' or 'witchcraft' in early European museums. Fernandes redirects the deferential gestures of ballet, professionalized in Louis XIV's court at the same moment of the objects' collection, to reanimate and apologize to them. Considering Lost Bodies, I explore how it is possible to nuance Western museums' public development narratives by engaging such artefacts without either ignoring their history or rejecting museums on account of their own.

Keywords: critical religion; ritual; enchantment; museums; post-development; Brendan Fernandes

\section{Introduction}

In 2015 Brendan Fernandes was invited by the Agnes Etherington Art Centre (Kingston, ON) and the Textile Museum of Canada (Toronto, ON) to critically interpret (what they refer to as) their collections of African art. The resulting exhibition, Lost Bodies, ran at the Agnes during its Winter season from 9 January 2016-10 April 2016 and was shown next at the Textile Museum from 9 November 2016-19 March 2017. It unites several thematically relevant works already completed by Fernandes for other shows with a number of new works. These include a series of photograph and silligraph ${ }^{1}$ collages of headdresses and ballet dancers' limbs, short looping films of ballet dancers interacting with masks and costumes, and textiles draped over empty plinths, as well as plinths printed with textile patterns. The former are essentially ways of putting bodies back into the empty space behind the masks. The latter are ways of 'clothing' stand-ins for bodies in their new ritual space - that of the museum. Given the nature of the collections involved in Lost Bodies as well as the nature of Fernandes' own aesthetic inquiry, all of the artefacts in question are ones that have some ritual significance. I consider the meaning of 'ritual' in more detail later, but suffice it to say here that some are objects made by people with special connection to spiritual forces, some belong in ceremony, and others might have been worn everyday for their magical properties. 
(Later I also address the concept of 'magic', but I use 'magical' here according to a broad religious studies conception, meaning things thought to bring desired effects to the user through the intervention of a spiritual or supernatural force). Yet other objects are simply ones that in some way reflect a supernatural ontology. Lost Bodies is therefore an excellent case study for exploring how witchcraft, spiritual, and magical worldviews are being dealt with in a museological context. But what is more, the collections it works with are excellent touchstones for exploring how this dealing might have to do with issues of concern to critical contemporary development research.

In what follows, I explore how Lost Bodies exposes the colonial violence of reading ritual objects as 'primitive' or 'witchcraft' and then re-reads ballet as similarly mystifying. I also argue that the exhibition reinterprets the museum itself as a ritual space, and reframes European modernity and even capital- and technology-mediated modernity as enchanted in this context. In doing so, I establish the museum as an agent of - and, to its credit, increasingly a self-reflexive critic of - development. After discussing the history of the museum as a 'civilising institution' I consider how Lost Bodies, as it travels through parts of Canada, speaks to diasporas in major urban centres and intervenes in the production of development knowledges and imaginaries locally, nationally, and globally. I then evaluate how well it does in situating its own knowledge. That is, what comment does it make about (what some development scholars persist in calling) ${ }^{2}$ 'premodern' society? How does it historically situate the knowledges of the communities embodied in the 'African collections'? Does it resist romanticizing these communities, as many critics of development are themselves critiqued for doing? ${ }^{3}$

I proceed by analysing some particular pieces in the exhibition in greater detail, drawing on analytical tools from development literature, museum studies literature, and religious studies literature. Overarching the points mentioned above, the main theoretical 
contribution of this paper is to explicitly link the concepts of witchcraft, spirituality, and magic to the concept of religion, bringing this insight and other knowledge derived from the field of religious studies to inform mainstream development studies literature. This literature, 'until very recently', featured 'no single article where religion or spirituality was the main theme'. ${ }^{4}$ By doing this, I advance a recent and important critique of development studies literature made by Ben Jones and Marie Juul Petersen that the small but growing body of research on religion and development is 'instrumental', 'narrow', and 'normative'. The present work provides an example of what they call 'something more open' and 'more critical', that is, a scholarly contribution 'looking at development policy ... practice' and research 'at a more conceptual level' through a religious studies lens, and 'exploring the symbols, signs and ceremonies which sustain development as a set of institutions, practices and meanings' ${ }^{5}$ This, as Jones and Petersen say, 'offers a way of questioning the objectivity of "development" while at the same time challenging conventional conceptions of religion" ${ }^{3}$ - the latter being something they themselves do only insofar as making this and one other equally cursory mention.

What Jones and Petersen miss in their critique that 'writing on "religion and development"' has rarely referenced 'ritual, traditions and inner belief" ${ }^{7}$ is that 'religion' is not an indigenous concept outside of the modern West. So while beginning to reference these Protestant touchstones of religiosity might indeed widen development studies' 'engagement with religion only as [faith-based] institutions and organisations,, 8 it would seem anachronistic to do so. As scholars of the 'critical religion' school find themselves having to continually point out, 'religion' is a relatively recent conceptual invention that has been applied to diverse global cultures as a way to pick out and compare analogues to (especially Protestant) Christianity. ${ }^{9}$

In the words of Talal Asad, '[t]he insistence that religion has an autonomous essence 
- not to be confused with the essence of science, or of politics, or of common sense - invites us to define religion (like any essence) as a transhistorical and transcultural phenomenon' ${ }^{10}$ But as many scholars have oft repeated since the 'linguistic turn' inaugurated by J. Z. Smith, it is not a sui generis thing. ${ }^{11}$ It is, in reality, a folk taxon, though one underpinned by powerful political agents. To explain, it is worth quoting at length from William Arnal and Russell McCutcheon in their 2012 The Sacred is the Profane: The Political Nature of 'Religion'. They write that part of 'the guiding impulse for intellectualist definitions of religion' [ie. those focusing on belief] is:

the archetypal Enlightenment contrast between 'dogma' on the one hand and 'rational and scientific' knowledge on the other. The Enlightenment appeal to sovereign reason (in contrast to 'dogma') was itself a rhetorical move in a larger political program in which ecclesiastical institutions (and the late absolutisms that derived some measure of legitimacy from them) could be subjected to persuasive critique from outside of the institutions in question. That the earliest academic efforts to define religion bear traces of this political program, albeit a century or more later, should alert us to the possibility that 'religion' itself may be a discursive invention of modernity, and especially of Enlightenment; its cogency may depend on the sociopolitical circumstances and agenda of the Modern world. This is not to say that [early anthropologists like] Tylor and Frazer — much less Müller — were necessarily advancing the political interests of the Enlightenment but, rather, that the success of the Enlightenment project had created an entity, 'religion', which these later thinkers attempted to theorize. $^{12}$

A central issue this line of thinking points to in Lost Bodies is how terms like 'witch/craft', 'shaman/ism', 'spirit/ual/ity', 'magic', and 'supernatural' derive their meaning in this Western museological context from their conceptual relationship with 'religion' and its discursive history.

In this case, actually, the term 'ritual' is really the first conceptual contact point with 'religion' - that is to say, 'ritual' is the conceptual link between 'religion' and concepts like 'witch/craft', 'shaman/ism', 'spirit/ual/ity', 'magic', and 'supernatural' in Lost Bodies - 
because of its centrality as an explicit theme in the exhibition. Though he is not coming from a religious studies perspective, Fernandes clearly suggests that if we can broaden the terms in which we conceptualize 'ritual' to think past the confines of some intuitive notion of 'religious ceremony', then ballet certainly fits the bill, and so does our very movement through the space of the gallery.

Before showing how Lost Bodies materializes these ideas, I must briefly describe the 'African collections' Fernandes has worked with in the exhibition, because their history is integral to the history of the museum as an agent of development.

\section{What's in a name? The 'African collections' and their provenance}

The 'Justin and Elisabeth Lang Collection of African Art' at the Agnes and the ‘African Collection' of the Textile Museum of Canada represent two of the best repositories of such objects in the country. What is known about the provenance of objects in each collection varies widely within them. For instance, some can be dated to the decade, some only to the century. At the Agnes, staff research has been able to identify the artists of only two sculptures from among their collection of over five hundred objects. That collection is comprised primarily of works by West and Central African peoples acquired over the twentieth century by Justin (1906-1989) and Elisabeth (1914-1990) Lang, amateur collectors and European refugees who settled in Montréal, Canada. According to the Agnes, the Langs 'held to a twentieth-century Modernist fine arts tradition that upheld the notion of aesthetic universals and embraced non-Western objects as works of art'. ${ }^{13}$ This collection therefore differs from 'earlier North American ethnographic showcases of specimens and souvenirs assembled by missionaries and military men'. ${ }^{14}$ But given the fact that the Langs donated an entirely anonymous collection, it departs also from the Western art historical model that links individual authorship with the prized concept of creative genius. 
The Textile Museum's collection is much larger and is browseable online by the categories of: type, region, materials, techniques, and period - but certainly not by artist. It includes objects made by peoples from North, East, West, Southern, and Central Africa, with an emphasis on North and East Africa. (The collections from the latter two regions number around five hundred while the others number closer to one hundred objects each). The museum began accessioning textiles in the 1970s and its donors include numerous private individuals.

One of the interventions Brendan Fernandes has staged in working artistically with these collections has been to accompany each piece, whether an installation, collage, or video, with a handheld didactic label giving information on the artist or people(s) who made the objects involved as well as the title of the artwork Fernandes created with them. In problematizing authorship, this strategy redistributes the locus of authorial knowledge and the power that comes with it, and with making display choices about art and artefacts. It becomes clear that curatorial and artistic choices are jockeying in this exhibition with the priorities of the people who made and used these objects in ceremony and in daily life.

Showing knowledge, power, and scopic control as being tightly related, the comment made by this naming strategy does not simply have to do with inviting audiences to consider similarities and differences between 'Western fine art' and 'African artefact'. (The exhibition can, nonetheless, be said to make a systematic case that both 'ordinary' and 'fine art' culture can be of equal social value, and that recognizing this depends - to use Stuart Hall's phrasing - on analyzing how museums 'encode' meanings in their objects and how gallery-goers 'decode' them ${ }^{15}$ ). Importantly, problematizing authorship through critical titling as well as collage and other assembly techniques (eg. bricolage, assemblage, pastiche) functions as a critique of the racist ideologies that enabled the collection of objects from colonized African peoples during European imperial expansion in the first place. These ideologies justified 
using the objects as a foil to European culture in the museums of the late nineteenth century or as merely an aesthetic mirror for modernist art in the galleries of the early twentieth century.

In working with the 'African collections', Fernandes - an artist of Indian descent, Kenyan born, Canadian raised, and now living in America - questions the very naming of these works as broadly 'African' in the first place. He does so in an effort to 'bring the notion of provenance as a history of ownership into view', and thereby interrogate 'colonial authorship of histories', and question notions of 'authenticity'. ${ }^{16}$ These are concerns of Fernandes' in his practice overall, but in the case of Lost Bodies particularly, the effect is to challenge the political agendas of the museum as a co-producer of development knowledge about postcolonial peoples ${ }^{17}$ with magical and spiritual worldviews. He questions hierarchies of value built around the sophistication of 'African' material culture vis à vis canonical Western forms, and how the aesthetic and technical achievements embodied in this culture reflect ontologies and epistemologies that are then invited (explicitly or implicitly) by the institution to be compared with Western modern norms.

The concept of 'co-production' here is noteworthy, and used advisedly, because the nature of Fernandes' critique involves a radical contextuality ${ }^{18}$ and reflexivity that demands accounts of all subjectivities engendered by the museological relationship - including that of numerous African peoples dispossessed of their production since 'the Scramble for Africa'; Northern, diasporic, tourist, and all other manner of visitors to these urban Canadian museums; and the professional positionalities authorized by the museum itself as an institution. Being as committed to careful contextualization as he is, Fernandes likewise confronts the 'hybrid and transitional nature' of his own identity ${ }^{19}$ in this exhibition by asking questions that dwell on his, as well as visitors', epistemological, moral, authorial, and economic relationships to the art and artefacts in question. 


\section{From the museum as 'civilising' institution to the museum as critic of 'development'}

Underlying specific aesthetic provocations in Lost Bodies is Fernandes' invocation of the history of the museum as a 'civilising' institution; a history perhaps best described by the English academic Tony Bennett in his seminal 1995 book The Birth of the Museum: History, Theory, Politics. Remembering this history is a key entry point where Lost Bodies can be read as making a contribution to thinking about development practices and imaginaries. Considering the exhibition this way is not about figuring out how to 'do development' among collaborators who diverge in their understandings of causality, expectations of efficacy, and moral sensibilities on account of holding fundamentally different ontologies (as for example in something like Jeffrey Haynes’2007 Religion and Development: Conflict or Cooperation?). Rather, it is about understanding how a certain institution - the museum - is linked with an archipelago of other institutions in producing knowledge about the development markers and capacities of supposedly 'primitive' peoples. Namely, those whose worldviews are 'enchanted' by magic, witchcraft, and spiritual realities. And it is about understanding how this development knowledge is produced for people who are positioned, in distinction, as knowing the 'truth' of religion, science, and civilisation.

As Bennett explains, the exhibitionary forms that developed in the nineteenth century were intended to let people see and be seen. The idea was that European working class 'masses' would be exposed to elite culture and society, and, in turn, emulate these examples in their own behaviour. This would happen thanks to social pressure and the panoptical effects of exhibitionary architecture such as London's Crystal Palace, a massive iron and glass structure which was built to host the Great Exhibition of 1851. Entailing grand building projects and drawing intensive tourism, such 'great shows' were intended to stimulate economic development as well as a rather narrow version of what might now be called 
'human development'. ${ }^{20}$ This involved building basic capacity in education, capacity in (highly contestable) values such as 'morality', and encouraging popular participation. At the same time, the expectation was that all strata of society would learn their place with respect to the 'inferior races' who were made out to be mired in mystification while Europeans were speeding ahead on the wings of reason - even as reason was understood as being perfectly compatible with the ideologically loaded new disciplines of social science, as well as with a Christian cosmology full of phenomena that were very much supernatural. ${ }^{21}$ As Bennett succinctly frames the issue:

in the context of late-nineteenth-century imperialism, it was arguably the employment of anthropology within the exhibitionary complex which proved most central to its ideological functioning. For it played the crucial role of connecting the histories of Western nations and civilizations to those of other peoples, but only by separating the two in providing for an interrupted continuity in the order of peoples and races - one in which 'primitive peoples' dropped out of history altogether in order to occupy a twilight zone between nature and culture. $^{22}$

It is crucial, therefore, to establish here that the emergence of the museum in general was never just an entertainment or educational phenomenon, nor was the art museum in specific ever just an art historical phenomenon. Rather, the birth of the museum was linked to the emergence of a wide range of institutions, from the explicitly educational ('history and natural science museums, dioramas and panoramas ${ }^{23}$ ), to the carceral (involving new technologies of vision in the pursuit of spectacle, surveillance, and discipline ${ }^{24}$ ) to the commercial ('arcades and department stores' ${ }^{25}$ ). All of these moreover 'served as linked sites for the development and circulation of new disciplines (history, biology, art history, anthropology) and their discursive formations (the past, evolution, aesthetics, man)' ${ }^{26}$

It is in dialogue with this history that the exhibition Lost Bodies operates. As the Agnes promotional material states: 'Fernandes' montage of classical dance and the collected object is concentrated around precise body language that raises questions about the visual and 
discursive habits that shape understandings of African art within Western museums'. ${ }^{27}$ Specifically, Lost Bodies performs a critique of the racist ideologies that enabled the collection of objects from colonized African peoples and made it acceptable to present them as evidence of 'superstition' or 'witchcraft' in comparison to 'civilised' European 'culture' and 'religion' in nineteenth and twentieth century museums. ${ }^{28}$

\section{A Ritual Reunion of Development, Religion, and Magic}

Lost Bodies reminds that 'while aesthetics may guide the production of art in Africa, often there are other social, religious, or political concerns that inform its design and use'. ${ }^{29}$ Just as 'the diverse arts of Africa were not suited to the aesthetic hierarchies and systems of classification established by art museums, ${ }^{30}$ neither are supernatural phenomena separable into a distinct domain that we conventionally call 'religion'. Rather, it would be more accurate to say that for many of the peoples whose objects are involved in Lost Bodies, religion was (and in some cases still is) lived continuously as part of an integrated worldview. Elements that might conventionally be referred to as 'religious' in Western discourse would have been (may still be) coextensive with culture as a whole, not differentiated as belonging to one among a suite of separate institutions to be selectively engaged. Lost Bodies demonstrates how Western museums can nuance public narratives of development by engaging ritual artefacts from societies with magical worldviews without ignoring this history and context. But while the host institutions have embraced accountability, and while the artistic premise has been conceived with conceptual sophistication, the conceptual nexus of 'religion', 'ritual', 'witch/craft', 'shaman/ism', 'spirit/ual/ity', 'magic', 'supernatural', etc. demands further critical attention. It is a crucial part of the development narrative in which Lost Bodies intervenes and we augment the critical force of the exhibition and of development studies frameworks if we explore it. 
As already noted, the objects selected by Fernandes are ritual objects, especially masks, headdresses, and clothing. So far, I have used the term 'ritual' unproblematically as a descriptor of repeatable meaning-making performances and the objects therein in a way that probably seems consistent with intuitive lay notions of the term. Certainly Fernandes deploys the concept of ritual this way. For instance, in describing the video 'As One' (Figure 1), he explains how the two dancers featured in the piece use 'gestures derived from classical French ballet', which are 'ritualized actions' conveying the 'formality and etiquette' belonging to the French court. ${ }^{31}$ And in the 'Move In Place' photo collage series, one didactic label describes a 'ceremonial headdress' whose magic was instilled by having been created in 'ritual seclusion'. Both of these examples reference the notion of ritual as pertaining to something stereotyped and special, or set apart (in other words, 'sacred' [see Knott 2013]).

But ritual suffers from the same normative and definitional problems as 'religion', and in the hands of religious studies scholars, has been called to similar account. Just as with religion, there is no one agreed upon definition of ritual. Though ritual is often discussed as a mode of religious or spiritual activity and ritual studies constitutes a major subfield of religious studies scholarship, we must resist any assumption that it is necessarily related to religion. Likewise to the critical religion scholars, the most influential contemporary ritual theorists ${ }^{32}$ respond to these problems by understanding ritual as a cultural strategy; not defending a final stance on its meaning, but studying discourses in which concepts of ritual are shaped and challenged. Lost Bodies embraces just this spirit of radical contextualism, and we can understand the exhibition that much better - and indeed other museological projects dealing with spiritual worldviews - if we appreciate how it responds to this definitional problem. By juxtaposing apparently secular discourses (ballet) with apparently spiritual ones (the variety to which the artefacts belong), Lost Bodies shows us that ritual is alive in each and perhaps many other places, besides. If we analyse both beside each other, it becomes 
possible to abstract a set of formal qualities and functions conventionally associated with 'ritual' in these different contexts.

Throughout the gallery, we begin to see a rhythm created by certain features, for instance, repetition, standardization, and solemnity (though, on occasion, exuberant intensity). We observe how these qualities are implicated for gallery-goers and for the 'lost bodies' in the development of dispositions and beliefs, the transformation of social relationships, the cementing of group bonds, and managing the flow of time. When we attune to these qualities and functions it becomes possible to see how the practiced, precise, dignified, and dignifying choreographies of ballet and our self-conscious, quiet movements that give wide berth around valuable works of art in the gallery, both fit the ritual bill. ${ }^{33}$ Drawing on his own past as a dancer, Fernandes posits ritualized movement as a lingua franca to mediate between the missing bodies of his title, ballet, the 'choreographies of the [museum] vault', ${ }^{34}$ and the visitor walking around the gallery. So it is not incidental that the items selected by Fernandes are ones that would have been worn by people involved in the performance of ritual. The aesthetic question posed by Fernandes about the movement common to all these scenarios is: what are the animating forces behind it, and how do they interact? The title of the exhibition, Lost Bodies, refers to the absence of animating agents in a context they could not have foreseen, one where their material labour, but not they themselves, would be sought after, but often for ethically suspect reasons. It is in order to redress the indignities visited upon objects from the so-called 'African collections' that Fernandes has redirected the deferential gestures of ballet, which was being professionalized in the court of Louis XIV at the same historical moment of the objects' collection, as an apology to them. It is therefore a détournement of the colonial impulse that re-animates ritual objects that can no longer perform for themselves. Fernandes' collages and videos reference the fact that ballet developed as a Western European form of deference to 
imperial powers (bowing to, performing for Louis XIV) at the same time parts of Africa were being colonized by the French and other European countries (Figure 2). Fernandes reminds us, as Christa Clarke and Kathleen Berzock affirm, that it is in these colonial enterprises - and not incidentally, many Christian missions - that so many museum artefacts were collected. In other words, the fact of Western museums having these artefacts comes out of the same imperialistic cultural impulses and the same historical moment as ballet. Fernandes materializes the confluence of these dynamics for his viewers. The point Sabina Magliocco observes with respect to religious mixing and matching pertains here more generally: that syncretic identity 'tends to emerge during periods of marked social transformation' such as colonization. ${ }^{35}$ Articulating these impulses, moments, and cultural forms, Fernandes uses aesthetic techniques of combination to refer to the hybridity of identity for colonized peoples, who must perform both traditional identities and colonially imposed ones.

In the video 'As One', two white ballet dancers, one male and one female, are shown directing slow, controlled, contemplative movements toward two masks raised up on plinths. The masks themselves are also gendered and known to be ethnically distinct. According to Fernandes:

the female mask covered with geometric designs is from ... the Kuba people - and was originally worn as the face of a female court historian who danced very carefully. The mask with a crest is from the Bobo people, and was performed as a vigorous whirlwind to portray a nature spirit with explosive energy. ${ }^{36}$

Painstakingly and by turns, paired with the mask matching their respective gender presentation, the dancers hold strenuous poses while touching the plinths and drawing their own faces intimately close to the masks. Ballet is taken out of service to colonial powers and used to subvert them by restoring dignity toward the artefacts they had simultaneously exoticized and desacralized. 
In tension with the elegance manifesting onscreen, the way that the viewer's reflexivity is demanded is in part by making them feel awkward, positively un-balletic, and in the way of the art. In Lost Bodies we see, for example, the deliberate placement of plinths in the course of obvious walking paths. In the final gallery room there is a kind of tease where 'As One', which is a four-channel video, shifts from one screen to the next, unpredictably forcing viewers to shuffle themselves around the room in order to watch it. As part of the audience, you wish you knew the codes of good gallery behaviour as well as the graceful dancers knew theirs. And although you often find yourself falling short of the ritual demands, it is hard to ignore the systematic case made by Lost Bodies that ritual and reverence are in all kinds of culture - in the act of visiting a gallery and in the performance of ballet as much as in, say, wearing a headdress for a rain-bringing ceremony.

\section{Cashing out the magic in modernity}

The multiplicity and hybridity highlighted by Fernandes' literal assembly of subjects and objects through his works and their labels are not the only such layerings in the exhibition. Indeed, this archaeological, or perhaps, better yet, palimpsestuous approach is how the artist keeps competing histories in view simultaneously with his own new interpretations. In one collage, 'Move in Place III', like in 'As One', concepts of gender and race are juxtaposed, collaged, and détourned. 'Move in Place III' repeats the shape of a Dogon door lock (whose form represents the twin male and female spirits said by the Dogon people to animate us all) until it forms a crown that sits atop two legs from en pointe dancers, one black and male, the other white and female.

Even as it refers to gender, racial, and other hybridities, such complexly edited work also speaks to the magic in modernity. Not just to the mystification of repressive political and economic ideologies, like social Darwinism, scientism, or the fetishization of the 'monstrous' 
and metastasizing world of commodities. ${ }^{37}$ But to the creative powers of the technologies that make Fernandes' own aesthetic techniques possible. And also to our reliance on what Michael Saler calls 'fictionalism', after the philosopher Hans Vaihinger, who 'argued that the selfreflexive character of modernity resulted in traditional beliefs being replaced by provisional fictions, which provided practical guidance as well as spiritual enchantments' ${ }^{38}$

According to Saler, over the past two decades 'a new historiographic position, if not consensus, has emerged that presents Western modernity as "enchanted"' or at least 'as enchanted as it is disenchanted' ${ }^{39}$ Both in public discourse and in scholarly work, narratives of modernity have been bound up with ideas about secularization and the even broader concept of disenchantment. That is to say, the idea (first made famous by Max Weber in 1917) that the modern Western world has lost the:

overarching meanings, animistic connections, magical expectations, and spiritual explanations ... formerly provided by religious world views; [that] the prevalent emphases on scientific progress, technology, and instrumental reason can be dehumanizing; [and that] the rapid changes of modern existence can yield feelings of anomie, fragmentation, and alienation. ${ }^{40}$

But, as Saler observes, there are corresponding ways the modern world has been reenchanted. It has been duped by the myth of its own technological mastery over nature, obsessed in entertainment culture with the monstrous and the magical, and enslaved by the irrationality of capitalism. ${ }^{41}$ And this is to say nothing of the way the so-called world religions have continued to flourish along with all manner of phenomena challenging the religion/secular binary. This is a position Saler describes as the "“antinomial” understanding of modernity as enchanted in a disenchanted way'. ${ }^{42}$ Looking at the rare artefacts and chimeric artworks gathered together by Lost Bodies in the didactic space of the museum, hardly could a phrase ring more true.

Equally germane to our discussion of Lost Bodies, many of the most fruitful 
conversations in the antinomial vein have gone on in postcolonial studies, a key example of which for Saler is Peter Geschiere's thesis on the 'modernity of witchcraft'. In the past two decades, Geschiere and other scholars like Roger Sansi, Luis Nicolau Parés, Stephan Palmié, and Julien Bonhomme have offered historicized explanations of the way witchcraft discourse arose in and about modernity. The argument has two main parts. One is that what is today called witchcraft emerged in the first place through a blending of colonial European beliefs and practices with African ones (see Sansi 2011 for an excellent example in which he traces the concept of 'fetishism' from the Portuguese feitiço). The other is that wherever the discourse of witchcraft occurs, it expresses anxieties about one or another of modernity's ‘interactional repertoires', in Bonhomme's tidy phrase - for instance, about social anonymity in the urban or digital environments considered by Fernandes in Lost Bodies and Bonhomme in his analysis of witchcraft rumours in West and Central Africa. ${ }^{43}$ But to this anthropological understanding of witchcraft we have to add the religious studies understanding that the concept of 'witchcraft' is also premised on the concept of religion itself having, at its heart, a "self-referential opposition to the nonmodern'. ${ }^{44}$ As Randall Styers claims, the dominant concept of religion, the one noted above as being biased toward an Enlightenment-era love of the mind and distaste for matter, lives on its difference from what became known instead as magic - the force behind occult practices, like 'witchcraft', that seek practical benefits from mysterious forces. Through the Protestant and Catholic reformations and the Age of Discovery, European intellectuals reduced the meaning of religion from a variety of external ritual expressions to a matter of internal cognition, even as they expanded the concept to designate a cross-cultural phenomenon. With the modern Christian discourse of religion, a variety of other cultural forms dealing with unseen realities could be linked categorically, but distanced from 'true religion' as primitive or heretical.

In focusing on the exchange between two economies of movement, that of the 
artefacts and that of ballet, Fernandes leaves this magic/religion dichotomy tacit, but understanding it is key to understanding what we are talking about in the first place when we speak of magic and witchcraft. What Fernandes does do is stress the absence of the animating force behind the masks and clothes by implying one within manufactured objects themselves. This is an aesthetic play on the anthropological concept of the fetish (an object invested with power because of its extraordinary provenance) and its Marxist extension in the "commodity fetish' (an object possessed of economic value apart from the labour it represents). In various ways, both fetish and commodity fetishism are products of an Atlantic modernity whose complex histories Fernandes is trying to visualize. In this modernity, slave labour was the first form of mass production; where things were invested with a value normally reserved for persons and persons were possessed as things. Especially in artworks depicting mask forms in mass produced materials, Lost Bodies visually conveys the insight articulated by Sansi that capitalism is not only comparable and adaptable to African sorcery, but is part of the same fetishism of modernity. ${ }^{45}$

'1978.412.367' (Figure 3) is one such piece, a neon hybrid mask/sign advertising the exhibition. It is the anonymous face of the exhibition, the first work you see in Lost Bodies, even before you enter the gallery space - it flashes like a commercial "OPEN" sign through the Agnes atrium window. ' 1978.412 .367 ' is both the accession number of the piece and its title. An accession number is a unique identifier that distinguishes an artwork from all other objects in a museum's collection. The title of this piece clearly puts the work into sharp relief against the market context in which it changed hands, traded for both financial and cultural capital, until it came to be part of a permanent collection. In this sense, '1978.412.367' is an invitation to consider your own role in the transnational economies that have enabled the trade of objects made by African peoples. It also points to another, more curious kind of exchange - and reversal - of value in which the mask it references might participate. 
According to the Agnes, this piece was 'inspired by an unattributed Bamana mask in the collection of the Metropolitan Museum of Art, New York' and another anonymous work that has been attributed to 'The Master of Buli' (a village in the eastern region of the Democratic Republic of the Congo). ${ }^{46}$ The shape of the mask in '1978.412.367', whose model was in wood, has been outlined in thin neon lights. Inside flashes what appears to be a decorative design, but actually spells out the question in Morse code: 'Who is the Master of Buli?' One might want to know, points out art critic Jen Graves, in case it might be possible to repatriate the work to the Master's descendants. ${ }^{47}$ By using this sobriquet rather than seeking the Master's name, the chance of the work and its value escaping the fine arts economy is obviated.

Another reading of ' 1978.412 .367 ' is to propose that it asks how the aesthetic value of an artwork changes when you translate it in material, space, and time; what if a mastercraft were just another cheap neon advert? In this sense, the work is therefore also an invitation to consider the discursive regimes that support the differentiation of objects made by African peoples into categories like 'art', 'artefact', and 'souvenir', and the ethical quandaries that result from engaging with them from a variety of subject positions - as a gallery-goer, consumer, and beneficiary of uneven global development. But a different issue it raises is: for whom is neon 'cheap'? As Jane Parish notes in her study of anti-witchcraft fetishes among the Akan in Ghana,

natural ingredients are often fastened to "foreign" objects, such as ballpoint pens, and made sacred by the priest who injects them with "special ingredients" only known about by the shrine god. These talismans are worn about the body in order to bring the wearer good fortune and protect him or her from evil magic and medicine used by one's enemies. ${ }^{48}$

These materially hybrid fetishes or talismans are crucial, especially, in the pursuit of wealth. In Parish's analysis, 'the accumulation of wealth in postcolonial African states continues to be a complex relation embodied in discourses about materialism and witchcraft' ${ }^{49}$ In this 
relation, such fetishes 'fuse the power of the local and the global in a deliberate mixture of material categories', just as they fuse the animate and the inanimate. ${ }^{50} \mathrm{But}$, as she notes, for many Western tourists, these items look disappointingly 'inauthentic' compared to the preconceived notions they have about what 'real' African souvenirs should look like. In contrast, 'the local assumption is that all natural matter is animated' such 'that even the most exotic objects can be appropriated and made effectively local by refashioning and attributing "local" asunsum ["spirit"] to them'. ${ }^{51}$ For the Akan, magic and money are inextricably linked, but perhaps only more tangibly than for Westerners. ' 1978.412 .367 ' gestures to these realities of capitalist globalization, pointing out how it constitutes its own 'irrational phantasmagoria, a world of beguiling and negative enchantments' ${ }^{52}$ In it, the imperative to accumulate both sanctions the moral absurdities of imperial conquest and reduces the value of social relations to spectacle and commodity exchange.

The concept of the commodity/fetish offers an incredibly parsimonious way to speak to the ideas mobilized by Lost Bodies, conjuring as it does the genre of movement by referencing both the circulation of commercial goods and the animation of 'spirited things' ${ }^{53}$ We can see that the artefacts brought into the 'African collections' achieved transatlantic mobility on account of the exotic qualities acquired through their particular histories. Ironically, for all their animation, they were unable to resist being moved into the museum precisely because of their designation as a lesser form of commodity based on their animating qualities. With this framing, Fernandes' use of ballet to apologize and to re-interpret them now appears all the more inspired. What the artist choreographs with the exhibition as a whole is a dance. Its magical movements are between so-called civilized objects and 'irrational' ritual, the local and the foreign, the present and the past, and, ultimately, the birth of the museum as a 'fetishised' space for producing knowledge about 'primitive' peoples. ${ }^{54}$ 


\section{Conclusion}

In terms of development literature, the critical stance taken by Lost Bodies is probably best aligned with certain post-development positions. In a survey of critiques of postdevelopment criticisms of development discourse, Aram Ziai refers to post-development as a school of theory that "bluntly rejects "development" simultaneously as a eurocentric discourse, an imperialist project and a meaningless concept', arguing instead for alternatives to development, "usually in the form of communities combining elements of "traditional" and "modern" culture, [and] regaining control in the fields of politics, economics and knowledge in opposition to the state, global capitalism and science.${ }^{55}$ Certainly the exhibition portrays the restructuring of Third World societies according to the image or the needs of the West as something 'malignant' and something that, especially through the theft of artefacts, leads to 'spiritual and material impoverishment' ${ }^{56}$ Explicitly, it contends that the pursuit of any

justice must be informed by understanding "imaginaries of "Global Africa" and exigencies of the continent in the current phase of capitalism, 57 - an understanding that takes account of modernity, money, and magic.

I argued earlier that the emergent literature on development and religion needs to account for the analytical fraughtness of the term religion and, thereby, for the relatedness of religion and other cultural phenomena like spiritual worldviews, witchcraft cultures, and magical ontologies. Building on this overarching theoretical point, I now want to conclude by reflecting on what Lost Bodies offers us in terms of the 'micro-level' detail of 'work[ing] through the complexity of [an] individual cas[e]', as Jones and Petersen advocate. ${ }^{58}$ One 'with less of an interest in relating the findings directly to the interests of development agencies and NGOs' and more to do with cultural production and its place in everyday lived realities. ${ }^{59}$ Though it avoids being 'instrumental' in this sense, it is worthwhile to note that such reflection may nonetheless be valuable to a different kind of institution - the museum. 
The kind of multifaceted reflection occasioned by Lost Bodies is especially relevant at a time when the building and expansion of museums is not only a regular feature of city planning in the West (the suite of 'creative cities' reports commissioned by a number of major Canadian centres is just one example of the use of material culture to draw tourism and retain talent ${ }^{60}$ ), but at a time when, according to the authors of a recent report on museum development and cultural policy in Latin America and the Caribbean, 'the specific values and creative potential of ... various heritages' are 'at long last' being 'perceived as a vital source of inspiration for development', and 'museums are being called upon to play a major role'. ${ }^{61}$

Lost Bodies, in addition to ritually reinvigorating objects with apologetic gestures or by literally giving them new legs through collage, could also be said to ask: what development work did spiritually significant 'African objects' do in their original contexts? Some of the objects in Lost Bodies, like a Bamana antelope headdress depicted in the 'Move in Place' series, were forged by craftspeople who would go into ritual seclusion to create them, and then used by shamans to contact the appropriate spirits in rain-bringing ceremonies. In this light, such objects could be seen as indigenous technologies of agricultural development, or perhaps as tools of policies intended to ensure the smooth functioning of a local food economy. Considering them in this way it becomes possible not just to note that removal from their places of origin means their magic has been removed as well, but possible to see how the kind of development work they might have done in context is different from what they could be said to do now in the museum - in their usual collections and in the hands of an artist like Fernandes.

Framed another way, we could even say the exhibition poses a different, more tonguein-cheek question: What kinds of culture evidence 'development', and which need to be developed? Fernandes suggests that, ironically, ballet needs to learn some social manners and that those steeped in the hierarchical order of its Euro-ascendant worldview need to practice 
their intercultural relations. It also suggests that a development framework that doesn't see ritual objects as indigenous agents of development, rather than curiosities that belong in the vault, might be disabling to both local religious (spiritual, magical, etc.) cultures and to selfdetermined development. It speaks to the importance of recognizing the relationship between the constitutive opposition of religion to magic and witchcraft, the exhibitionary complex, and development thinking broadly conceived. As Jones and Petersen point out, since the discourse on religion and development has been driven largely by funding offered by governments and development NGOs rather than the independent curiosities of academic researchers, 'the concern is with the positive and practical contribution religion makes to development (defined as policy and practice) ${ }^{6}{ }^{62}$ Here, I hope to have used Lost Bodies as a way to turn that question around and answer instead to: what goods and what harms does development do to 'religion', as both a lived experience and a densely networked concept.

Disclosure Statement

The author has no financial interest or benefit arising from the direct applications of this research.

Acknowledgements

The author wishes to acknowledge the time and generosity of the Agnes Etherington Art Gallery, especially Jan Allen, Sunny Kerr, and Carina Magazzeni, and the artist Brendan Fernandes. Thanks also to the students of RELS 202 and SOCY 362 for their insights on Lost Bodies in lively class discussions and in their assignments.

Notes

1. According to a definition used by the Agnes curators (found in the glossary of a website called ArtTownGifts.com), siligraphy is a 'water-less planographic printmaking process based on the repellence of ink and silicone. Designs are drawn or painted with water-soluble art materials onto ground glass. The surface is then coated with silicone, covering the non-printing 
areas of the image and leaving the exposed areas to be coated in ink applied with a roller. The print is then made by pressing paper against the inked drawing'.

2. In making this comment, I mean to acknowledge critiques like Bruno Latour's seminal We Have Never Been Modern and those that have followed in its vein, like Peter Geschiere's The Modernity of Witchcraft.

3. See, for example, Ziai, "The Ambivalence of Post-Development."

4. Jones and Petersen, “Instrumental, Narrow, Normative?" 1291-2.

5. Ibid., 1301-2.

6. Ibid., 1301.

7. Jones and Petersen, 1298. Their review article delves into the contemporary religious studies literature only to the extent of acknowledging that the debunking of the strong secularization thesis [that religion is disappearing in the face of modernity] has helped to explain the persistence of religion as a public force in development work.

8. Ibid.

9. It is important to note, however, that today, thanks to strong Evangelical missionizing and other globalizing cultural forces, we see a great deal of syncretism between, especially, charismatic forms of Protestant Christianity like Pentecostalism, and local traditions in many African countries. See, for example: de Witte, "Electric Touch Machine Miracle Scam." 10. Asad, Genealogies of Religion, 28.

11. The linguistic turn is not without its critics. For an excellent recent example, see Donovan O. Schaefer's Religious Affects: Animality, Evolution, and Power, in which he does not dispute that 'religion' is a categorical construction, that it is historical, or that it is about power, but rather he proposes that religious practices might exist before concepts, and that power is 'not limited to the plane of language'. Schaefer, Religious Affects, 7.

12. Arnal and McCutcheon, Sacred is the Profane, 20.

13. Agnes Etherington Art Centre, "Justin and Elisabeth Lang Collection". https://agnes.queensu.ca/collections/african/.

14. Ibid.

15. Hall, "Encoding/Decoding."

16. Fernandes, “Artist Statement.” http://www.brendanfernandes.ca/new-page/.

17. It is important to note that many scholars have identified problems with the term 'postcolonial'. For a summary, see: Brians, "Postcolonial Literature."

http://public.wsu.edu/ brians/anglophone/postcolonial.html.

18. I use the phrase 'radical contextuality' in the cultural studies tradition after Lawrence Grossberg, who uses it to describe cultural studies as something that 'rather than practices ... always constitutes its object as an alliance, a set of relations among practices (not all of which need be textual, symbolic, signifying nor even discursive)'. Grossberg, "Cultural Studies," 35. 
'Cultural studies' radical contextuality affects its theory and politics, which must be related not only to its historical context but to its institutional context as well'. Grossberg, "Cultural Studies," 38.

19. Fernandes, "Artist Statement."

20. For a revisiting of this concept in light of radically democratic goals, see: Anderson, "Human Development."

21. For a fuller discussion of the relationship between reason and Christianity, see: Vattimo and Girard, Christianity, Truth, and Weakening Faith.

22. Bennett, "Birth of the Museum," 77.

23. Ibid., 59.

24. See: Foucault, Discipline and Punish.

25. Bennett, 59.

26. Ibid.

27. Agnes Etherington Art Centre, "Brendan Fernandes: Lost Bodies."

https://agnes.queensu.ca/exhibition/brendan-fernandes-lost-bodies/.

28. Clarke and Berzock, "Representing Africa."

29. Ibid., 4.

30. Ibid.

31. Fernandes, “As One.” http://www.brendanfernandes.ca/asone/9tfq0y3s9gvjnhj65nicci57ctpwe6

32. Two notable examples are Ronald Grimes and Catherine Bell.

33. For further illustration, we could swap out 'religion' with 'ritual' and substitute any substantive definition of it in the following passage from Arnal and McCutcheon:

'All definitions of religion in terms of spirit-like or god-like entities - whether the classical definition of Tylor, more recent anthropological definitions like that of Spiro (1966), or current cognitively oriented definitions (e.g., Sperber 1996; especially interesting is Stowers 2007: 14 15) - come to grief on precisely this issue: They assume a distinction based on an intuitive modern understanding of 'religion', which they then read into the data, separating things that their own stated definition, rigorously applied, would not actually distinguish (Zeus from Superman, imaginary friends from spirits, etc.; cf. also Atran 2002: 13-14)'. Arnal \& McCutcheon, Sacred is the Profane, 24-5.

34. Agnes Etherington Art Centre, "Brendan Fernandes: Lost Bodies."

35. Magliocco, "Neopaganism," 51.

36. Fernandes, "Projects: As One.” http://www.brendanfernandes.ca/as-one/.

37. This is from Marx via Palmié's paraphrase of 'ungeheure Warensammlung' - 'a term Marx uses on the first page of Das Kapital to characterize his own social formation', 852. 
38. Saler, "Modernity, Enchantment, and Fictionalism."

http://blogs.ssrc.org/tif/2013/12/20/modernity-enchantment-and-fictionalism/.

39. Saler, "Modernity and Enchantment," 692.

40. Ibid., 695; 693.

41. There is a florescence of work on this issue, but one of the most interesting and succinct recent pieces comes from an object-oriented philosopher - see: Bryant, "Ages of Monsters." https://larvalsubjects.wordpress.com/2015/11/19/ages-of-monsters-of-gods-and-monsters/.

42. Saler, "Modernity and Enchantment," 694.

43. Bonhomme, "The Dangers of Anonymity," 205.

44. Styers, Making Magic, 4.

45. The author wishes to thank an anonymous reviewer for the eloquent phrasing of this comparison.

46. Agnes Etherington Art Centre, "Teachers' Notes: Wild Wires." https://agnes.queensu.ca/wp-content/uploads/2016/01/TeachersNotes_WildWires_2016.pdf. 47. Graves, "SAM Invokes New Spirits in the Ambitious Disguise: Masks and Global African Art." http://www.thestranger.com/visual-art/features/2015/06/24/22437203/sam-invokes-newspirits-in-the-ambitious-disguise-masks-and-global-african-art.

48. Parish, "Free Market, Black Market," 131.

49. Ibid., 118.

50. Ibid., 131.

51. Ibid., 132.

52. Saler, "Modernity and Enchantment," 708.

53. Johnson, Spirited Things: The Work of 'Possession' in Afro-Atlantic Religions.

54. Again the author thanks the same reviewer as above for articulating this additional level of the way movement operates in the exhibition.

55. Ziai, "The Ambivalence of Post-Development," 1045.

56. Ibid., 1047.

57. Agnes Etherington Art Centre, "Brendan Fernandes: Lost Bodies."

58. Jones and Petersen, 1298-1301.

59. Ibid.

60. Inspired by the expansion of the 'culture industries' in England and work on the so-called 'creative class' by researchers like Richard Florida, these are prepared by the Vital Signs Community Foundation. http://communityfoundations.ca/vitalsigns/.

61. Arjona et al., "Museum Development and Cultural Policy," 88-9.

62. Jones and Petersen, 1297. 
Bibliography

Anderson, Tim. "Human Development, the State and Participation." Development Studies Research 1, no. 1 (2014): 64-74.

Arjona, Marta, Frances Kay Brinkley, Fernanda Camargo-Moro, Roderick C. Ebanks, Manuel Espinoza, Felipe Lacouture, Luis G. Lumbreras, Aloisio Magalhaes, and Grete Mostny. "Museum Development and Cultural Policy: Aims, Prospects and Challenges." Museum International 66, nos. 1-4 (2014): 88-97.

Arnal, William, and Russell McCutcheon. The Sacred is the Profane: The Political Nature of “Religion.” New York: Oxford University Press, 2012.

Asad, Talal. Genealogies of Religion: Discipline and Reasons of Power in Christianity and Islam. Baltimore: Johns Hopkins University Press, 1993.

Bennett, Tony. The Birth of the Museum: History, Theory, Politics. New York: Routledge, 1995. Reprint, New York: Routledge, 2013. Page references are to the 2013 edition.

Bonhomme, Julien. "The Dangers of Anonymity: Witchcraft, Rumor, and Modernity in Africa." HAU: Journal of Ethnographic Theory 2, no. 2 (2012): 205-33.

Clarke, Christa and Kathleen Bickford Berzock. "Representing Africa in American Art Museums: A Historical Introduction." In Representing Africa in American Art Museums: A Century of Collecting \& Display, edited by K.B. Berzock and C. Clarke, 3-19. Seattle: University of Washington Press, 2011.

de Witte, Marleen. “The Electric Touch Machine Miracle Scam: Body, Technology, and the (Dis)authentication of the Pentecostal Supernatural." In Deus in Machina: Religion, Technology, and the Things in Between, edited by J. Stolow, 1-22. New York: Fordham University Press, 2012.

Foucault, Michel. Discipline and Punish: The Birth of the Prison. Translated by A. Sheridan. London: Allen Lane, 1977.

Geschiere, Peter. The Modernity of Witchcraft: Politics and the Occult in Postcolonial Africa. Charlottesville: University of Virginia Press, 1997.

Grossberg, Lawrence. "Cultural Studies: What's in a Name? (One More Time)." In Media/Cultural Studies: Critical Approaches, edited by R. Hammer and D. Kellner, 25-48. New York: Peter Lang, 2009.

Hall, Stuart. "Encoding/Decoding." Reprinted as edited extract from "Encoding and Decoding in Television Discourse," CCCS Stencilled Paper no. 7, 1973, in Media and Cultural Studies: Key Works, edited by M.G. Durham and D. Kellner, 163-173. Malden: Blackwell Publishing, 2006.

Haynes, Jeffrey. Religion and Development: Conflict or Cooperation. Basingstoke: Palgrave, 2007. 
Jones, Ben and Marie Juul Petersen. "Instrumental, Narrow, Normative? Reviewing Recent Work on Religion and Development." Third World Quarterly 32, no. 7 (2011): 1291-1306.

Johnson, Paul Christopher, ed. Spirited Things: The Work of 'Possession' in Afro-Atlantic Religions. Chicago: University of Chicago Press, 2014.

Knott, Kim. "The Secular Sacred: In-between or Both/And?" In Social Identities Between the Sacred and the Secular, edited by Abby Day, Giselle Vincett, and Christopher R. Cotter, 145-160. Farnham: Ashgate, 2013.

Landy, Joshua and Michael Saler, eds. The Re-Enchantment of the World: Secular Magic in a Rational Age. Stanford: Stanford University Press, 2009.

Latour, Bruno. We Have Never Been Modern. Translated by C. Porter. Cambridge: Harvard University Press, 1993.

Lee, Lois. Recognizing the Non-Religious: Reimagining the Secular. Oxford: Oxford University Press, 2015.

Magliocco, Sabina. "Neopaganism.” In The Cambridge Companion to New Religious Movements, edited by O. Hammer and M. Rothstein, 150-166. New York: Cambridge University Press, 2012.

Meyer, Birgit and Peter Pels, eds. Magic and Modernity: Interfaces of Revelation and Concealment. Stanford: Stanford University Press, 2003.

Palmié, Stephan. "Thinking with Ngangas: Reflections on Embodiment and the Limits of Objectively Necessary Appearances." Comparative Studies in History and Society, 48 (2006): 852-86.

Parish, Jane. "Free Market, Black Market: Anti-Witchcraft Shrines and Fetishes Among the Akan." In Magical Interpretations, Material Realities: Modernity, Witchcraft, and the Occult in Postcolonial Africa, edited by H.L. Moore and T. Sanders, 118-135. New York:

Routledge, 2001.

Saler, Michael. "Modernity and Enchantment: A Historiographic Review." The American Historical Review 111, no. 3 (2006): 692-716.

Sansi, Roger. "Sorcery and Fetishism in the Modern Atlantic." In Sorcery in the Black Atlantic, edited by L.N. Parés and R. Sansi. Chicago: University of Chicago Press, 2011.

Styers, Randall. Making Magic: Religion, Magic and Science in the Modern World. New York: Oxford University Press, 2004.

Vattimo, Gianni and René Girard. Christianity, Truth, and Weakening Faith: A Dialogue. Edited by P. Antonello. Translated by W. McCuaig. New York: Columbia University Press, 2010.

Ziai, Aram. "The Ambivalence of Post-Development: Between Reactionary Populism and Radical Democracy.” Third World Quarterly 25, no. 6 (2014): 1045-1060. 


\section{Figure Captions}

Figure 1. Still from 'As One'. Brendan Fernandes. 2015. Video. Credits: Video performance by Ezra Thomson and Sarah Pasch of the Pacific Northwest Ballet. Videography by Aaron Bourget. Editing by Kevin Dejewski. Sound by John Luther. Originally commissioned by the Seattle Art Museum. C [Brendan Fernandes]. Reproduced by permission of the artist. Permission to reuse must be obtained from the rightsholder.

Figure 2. 'Move in Place III'. Brendan Fernandes. 2015. Digital photographic collage. Produced in collaboration with the Agnes Etherington Art Gallery, Queens University, Kingston, ON, using images and 3D scans of objects from the Seattle Art Museum African collection and The Justin and Elisabeth Lang Collection of African Art at the Agnes. (C) [Brendan Fernandes]. Reproduced by permission of the artist. Permission to reuse must be obtained from the rightsholder.

Figure 3. '1978.412.367'. Brendan Fernandes. 2010. Glass; neon; clear Plexiglas; transformer; wires. Purchased by the Agnes Etherington Art Centre with the support of the Canada Council for the Arts Acquisition Grants program and the Donald Murray Shepherd Fund, 2013 (56-019). (C) [Brendan Fernandes]. Reproduced by permission of the artist. Permission to reuse must be obtained from the rightsholder.

Figure 4. 'Move in Place II'. Brendan Fernandes. 2015. Digital collage with works from The Justin and Elisabeth Lang Collection of African Art. Collection of the artist. This image doubles and mirrors a photograph of a male Chi Wara headdress, made by a Bamana artist from Mali out of wood, metal, and pigment. Reproduced with permission of the artist. (C) [Brendan Fernandes]. Reproduced by permission of the artist. Permission to reuse must be obtained from the rightsholder. 